\title{
Canvas B.M. in the global revolutionary era of digitisation in the industry 4.0: A review
}

\author{
Petra Domanižová ${ }^{1, *}$, Nikola Janíčková ${ }^{1}$ \\ ${ }^{1}$ Brno University of Technology, Faculty of Business and Management, Kolejní 2906/4, 61200 Brno, \\ Czech Republic
}

\begin{abstract}
.
Research background: Industry 4.0, also known as the Fourth Industrial Revolution, describes the digitisation of the manufacturing industry. The transition to 4.0 is crucial for manufacturing companies to maintain a competitive advantage and take advantage of new opportunities. This article contributes to research with a framework for the description, analysis, and classification of Canvas B.M. for 4.0.

Purpose of the article: The following report provides a review of the literature to expand our knowledge of how Industry 4.0 affects business models. This article aims to specify and map the level of knowledge about the Canvas business model and its application in the new revolutionary era of the digital world in the manufacturing industry 4.0. The findings deepen the understanding of how 4.0 affects the manufacturing industry, B.M., and the behaviour of the current economic environment.

Methods: A literature review. Then the comparison of the author's views on the use of the business model, innovation, and adaptation under the influence of digitisation. The literature survey was conducted in articles indexed in the Web of Science and Scopus to carry out a critical analysis of collected data and the exposition of some conclusions and future research opportunities.

Findings \& value added: A lot of research in the field of industry 4.0 using Canvas B.M., but very often, the view of the Czech business environment is neglected. Focusing on this area may lead to future research. This literary review focuses on the latest literature.
\end{abstract}

Keywords: Canvas business model ; digitisation ; globalisation ; industry 4.0

JEL Classification: $M 15 ; M 21$

\footnotetext{
${ }^{*}$ Corresponding author: petra.domanizova@,ceitec.vutbr.cz
} 


\section{Introduction}

Industry 4.0 (I4.0), also known as the fourth industrial revolution, describes the digitalisation of manufacturing industries. The transition to I4.0 is crucial for manufacturing companies to maintain competitive advantage and catch new opportunities. The Industry 4.0 concept was named from the fourth industrial revolution that is currently underway. It was founded a few years ago in Germany, and its mission is to solve the situation caused by the Fourth Industrial Revolution, which was caused by the Internet. Its essence is digitisation, the expansion of high-speed Internet, the development of smart technologies and communication. Most research has focused on the technological aspects of I4.0 in the form of product and process innovations. [1]

However, digitisation does not only affect consumers - it affects the industry. Thanks to the growing demands of customers arising thanks to the Internet, there is also growing pressure on manufacturers to produce and deliver products quickly, with high quality, precisely tailored to customer requirements, at the cost of mass production. Investing in digitisation is essential for the growth of all industrial companies, regardless of their size or industry. For example, the company Siemens, a leader in technological innovation, already has a solution for digitising production or a digital enterprise for its customers today. Siemens products and software solutions help digitise the entire development and manufacturing process and cover the entire product or manufacturing value chain. [2]

One of the main reasons for creating the Industry 4.0 concept was the need to reduce the time needed to launch a new product on the market while allowing more significant differentiation of production according to the needs of individual customers. The industry needs to shorten the time to market without losing quality. All this must be realised with higher energy efficiency, resp. saving material resources. [2]

Industry 4.0 as such unifies the physical, information and data components not only of the production environment itself. It connects machines, storage and logistics systems and other technological components into one unit. An entirely digitised automated system brings significant improvements to all business processes. At the heart of this concept is the so-called "Smart Factory". This is a critical element of the transition to a digitised and automated whole. It can autonomously manage and at the same time streamline the complete production process. The Czech concept of I4.0 is broader than the world concept. It is not just a Smart Factory, but a digital environment into which the company is gradually transforming. The Czech concept focuses more on the customer and a smart product or service. [3]

The most valuable businesses in the world have embraced digital business models. According to Financial Times U.K., seven out of the ten most valuable companies in the globe in 2010 and 2017 are digital businesses. A digital business model is transforming several businesses around the world, examples of which are Alphabet (Google), Facebook, and Amazon. Many authors describe the linkage between Internet and internationalisation and emphasise the impact of technological development in market entry. [4]

The business model is considered a comprehensive concept that cannot be easily defined. There are many different interpretations of the concept of business model, both from a scientific and a practical point of view. These interpretations use terms such as attitude, description, structure, framework, tool or method, and others to describe business models. All of these designations, in a sense, agree with what the business model expresses. At the same time, however, they confuse as to what the business model means, as there is no single definition, one view of this concept that would capture it from all angles of its possible expression. [5] 
Argue that a business model (BM) can be described as "the way a company or company network seeks to make money and create value for customers" (Haaker, Faber, Bouwman, 2006) and can be defined as a plan describing service definitions and the intended value for the target group, the sources of income and the provision of the service delivery architecture, including a description of the resources required and the organisational and financial agreement between the participating entrepreneurs, including a description of their roles and cost-sharing. [6]

One of the best known and most widely used business models is the Canvas model, which translates as "business plan scheme". This model was designed by Alexander Osterwalder, an entrepreneur and innovator in business models. It is an alternative to a large business plan and can be easily and relatively quickly changed and adapted to current conditions. The Canvas graphic scheme can be divided into the left side, which identifies the product, and the right side, which deals with the market. [7]

Over 5 million users use this model, and the book in which this model is described has been translated into thirty world languages and has sold over a million copies. This business model is used by many companies around the world, mainly due to the simplicity of its creation and possible changes. [8]

In this paper, we will address the influence of Industry 4.0 on sustainable business models.

\section{Theoretical Background / Literature Review}

This chapter will outline the theoretical background of future research. The individual concepts and the current state of knowledge in individual areas of research will be explained.

\subsection{Business models (BM)}

To identify the B.M. for I4.0, we first distinguish general concepts of B.M. without their relation to I4.0. Despite the extensive research of B.M., there is no commonly accepted interpretation of the definition has not yet been established [9].

Among the best-known definitions of a business model are those, who describe a business model as "showing the interconnectedness of content, structure, and transaction management that are designed to add value to the business by leveraging business opportunities." [10] Who have already included in the definition the concept of strategy "business model is a reflection of the implemented corporate strategy", who created definitions of business model. [11]

Argue that the business model is essential because it concerns how to commercialise a product or technology and create value. [12] The product or technology itself does not create value without an efficient and valuable business model.

It is also possible to define a business model as the logic, according to which a company that works creates value for all stakeholders. [11]

Focus on innovation of business models for Industry 4.0, i.e. the implementation of cyber-physical systems across the value chain and the far-reaching digitisation of products and processes is considered a significant change in our current industrial system. [13] They define the business model as a managerial hypothesis about what customers want, how they want it, how a business can organise itself to meet its needs best and get paid and make a profit. [14] 


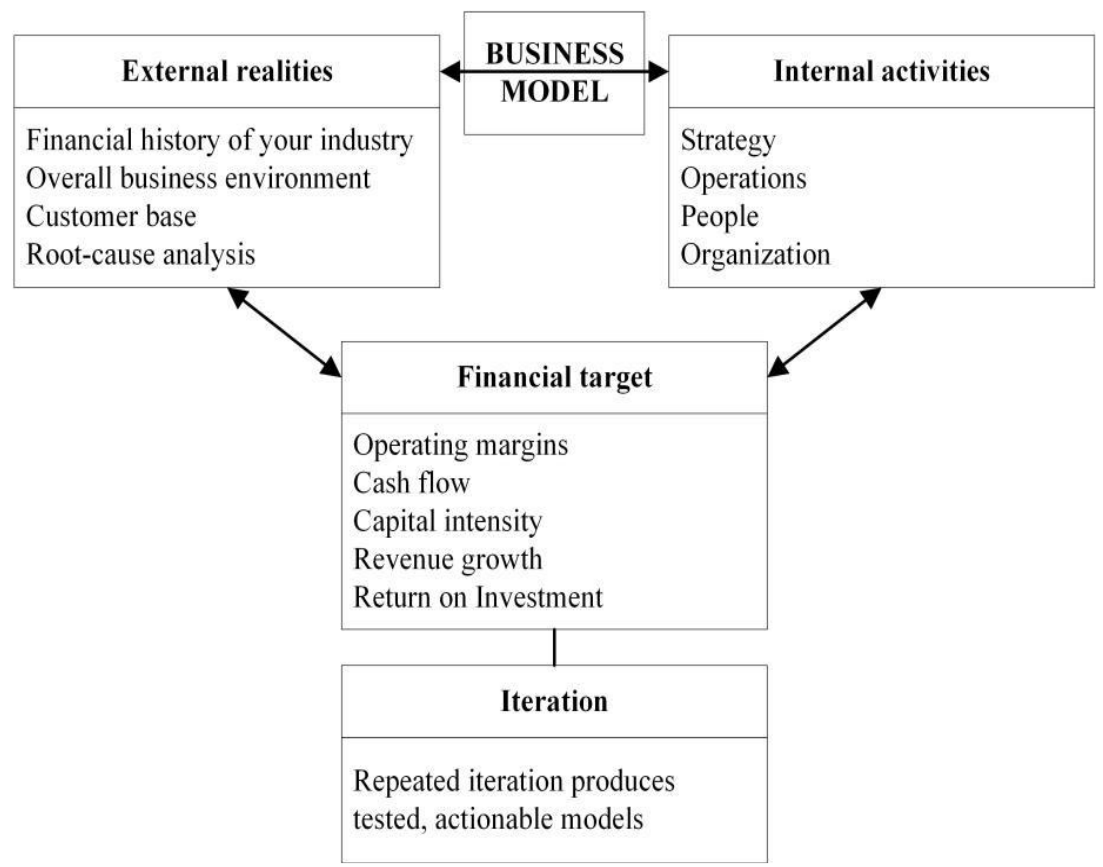

Fig. 1. The base business model [15]

\subsection{The role of business models in Industry 4.0}

Before we define the standard concepts of the digital business model and digital business process, it is first necessary to understand the core of the concept of digitisation. With the ongoing transformation of digital technologies, digitisation is intelligent business and value process using information and communication technologies such as big data, cloud and mobile computing, the Internet of Things and social software. [16]

Several concepts related to Industry 4.0 have been discovered. - for example, the "fourth industrial revolution" [17] or the "intelligent factory" [18], which were used to describe a new industrial scenario dominated by information technology and connectivity. Furthermore, e.g. Production of cyber-physical systems [19], advanced manufacturing, digitisation [20] [18], the industrial Internet of Things. [21]

The whole concept of Industry 4.0. focuses on the implementation of intelligent products and production processes by integrating modern information and communication technologies. [22]

Although B.M. research for I4.0 is immature, B.M. research for some topics related to I4.0 have been well researched, namely: open innovation (O.I.) and crowdsourcing, bulk customisation, product service systems (P.S.S.) and IoT. These types of B.M. are strongly associated with I4.0 B.M. because of all are permitted or supported by primary technical factors I4.0 B.M.: C.P.S., IoT and smart factories.

The role of business models in Industry 4.0 is significant. Every company has a business model and uses it to manage its processes. Therefore, when introducing Industry 4.0 , it is first necessary to modify the business model to meet the requirements of the Fourth Industrial Revolution. Many studies from around the world confirm this step and its importance. Man et al. explore how to use business models in Industry 4.0 successfully. The authors created a scheme that connects sustainability and industry 4.0 to the business 
model. [23] Business model innovation through industry 4.0 can, therefore, generate many advantages, intensifying customer relationships and bringing them to mutually lively medium and long-term relationships. At the same time, however, this innovation leaves many open challenges, including the increasing need for a qualified workforce, financial resources and consumer resistance to change. [24]

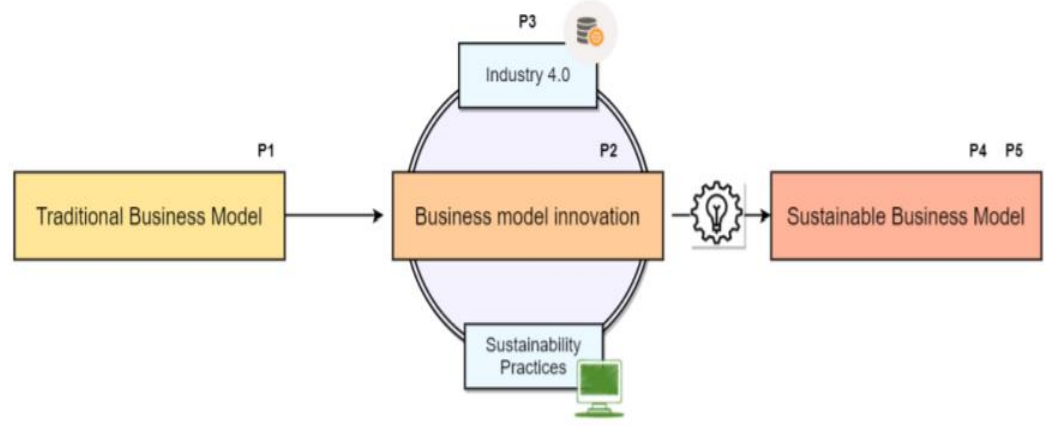

Fig. 2. Conceptual Framework [24]

\subsection{Business model CANVAS}

The Canvas business model, as the answer to previous results, ranks among the widely used, clear-cut and transparent business models. The authors also emphasise the economic and social benefits of the business model [25]. B.M. Canvas is divided into nine interconnected components such as offering value to the customer, segments, customer relations, channels, key resources, key activities, partners, costs and revenues. It can help in use above all users who adopt profit and purpose to support more sustainable value creation in itself [8], in practice the environmental and social value is implicitly emphasised behind a more explicit "profit in the first place" or economic value orientation. Ideally, exploring business models should be done as a whole, but it is also possible to explore selected parts of the model. The author appeals to the importance of adapting the business model to customer needs. Because a business model works anywhere in the world does not mean it will work in Europe.

Table 1. Specification of parameters in business model

\begin{tabular}{|c|c|c|c|c|}
\hline $\begin{array}{l}\text { Key } \\
\text { partners } \\
\text { (KP) } \\
\text { Who are our } \\
\text { Key } \\
\text { partners? } \\
\text { Who are our } \\
\text { Key } \\
\text { suppliers? } \\
\text { Which Key } \\
\text { resources are } \\
\text { we acquiring } \\
\text { from } \\
\text { partners? } \\
\text { Which Key } \\
\text { activities do } \\
\text { partners } \\
\text { perform? }\end{array}$ & $\begin{array}{l}\text { Key activities } \\
\text { (KAs) } \\
\text { What Key } \\
\text { activities do our } \\
\text { Value } \\
\text { Propositions } \\
\text { requires; our } \\
\text { distribution } \\
\text { channels; } \\
\text { customer } \\
\text { relationships; } \\
\text { revenue streams? }\end{array}$ & $\begin{array}{l}\text { Value } \\
\text { propositions } \\
\text { (VP) } \\
\text { What value do we } \\
\text { deliver to the } \\
\text { customer? } \\
\text { Which one of our } \\
\text { customer's } \\
\text { problems are we } \\
\text { helping to solve? } \\
\text { What bundles of } \\
\text { products and } \\
\text { services are we } \\
\text { offering to each } \\
\text { Customer } \\
\text { Segment? } \\
\text { Which customer } \\
\text { needs are we }\end{array}$ & $\begin{array}{l}\text { Customer } \\
\text { Relationship } \\
\text { (CR) } \\
\text { What type of } \\
\text { relationship does } \\
\text { each of our } \\
\text { Customer? } \\
\text { Segments expect } \\
\text { us to establish and } \\
\text { maintain with } \\
\text { them? } \\
\text { Which ones have } \\
\text { we established? } \\
\text { Who are they } \\
\text { integrated with } \\
\text { the rest of our } \\
\text { business model? } \\
\text { How costly are }\end{array}$ & $\begin{array}{l}\text { Customer } \\
\text { Segments } \\
\text { (CSs) } \\
\text { For whom } \\
\text { are we } \\
\text { creating } \\
\text { value? } \\
\text { Who are } \\
\text { our most } \\
\text { important } \\
\text { customers? }\end{array}$ \\
\hline
\end{tabular}




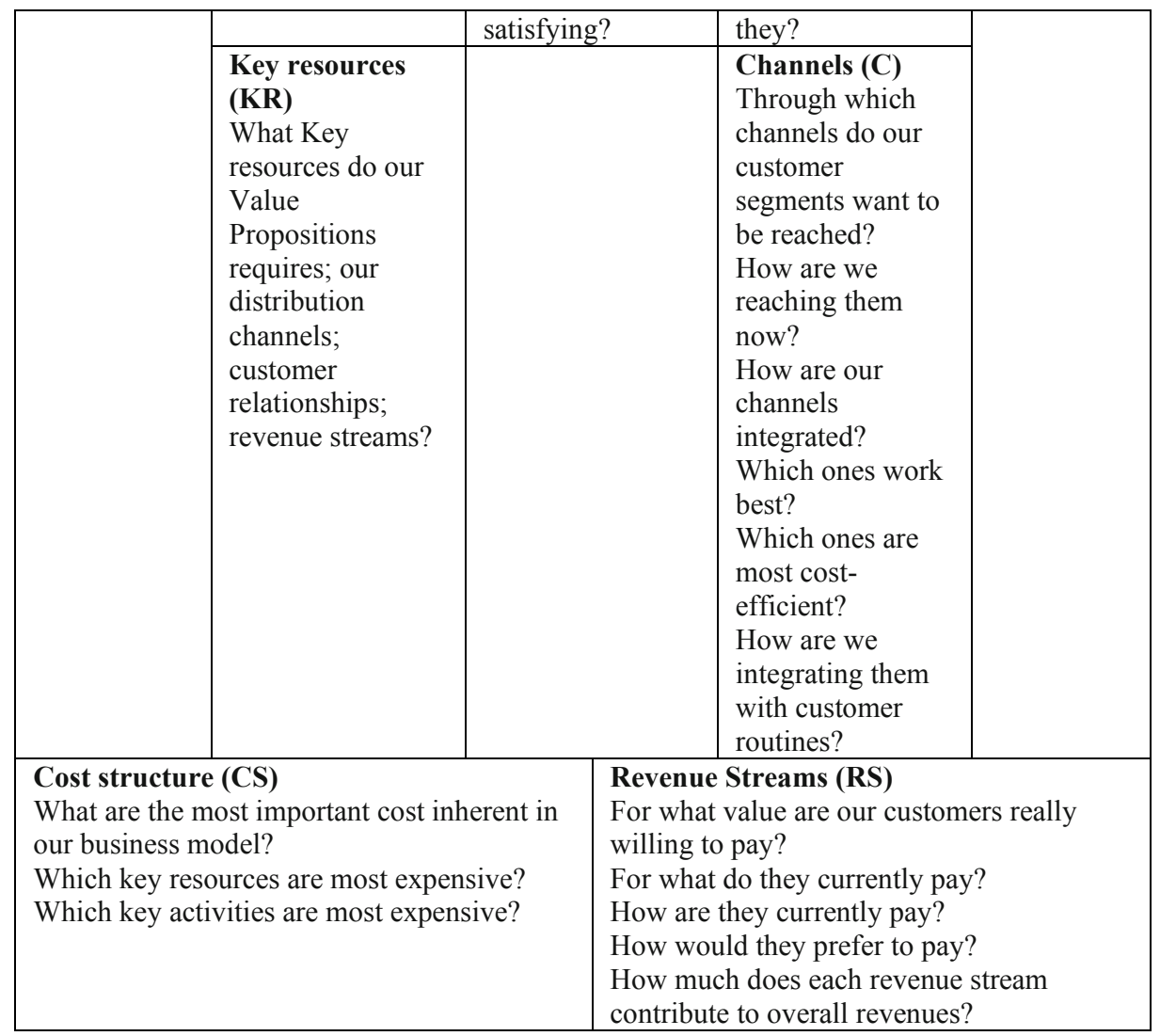

Source: Canvas [26]

\section{Methodology}

The purpose of the research as a basis for this paper is to find a literature review and comparison of the author's views on the use of the Canvas business model in the new era of digitisation. This article summary aims to compare the authors' opinions. Focusing on this area may lead to future research. This literature review focuses on the latest literature.

This research was supported by two books on Industry 4.0 in the Czech Republic, business models and related management processes. The first book is "Industry 4.0 - A Challenge for the Czech Republic" and the second book is "Generating a Business Model: A Handbook for Visionaries, Actors and Challengers". [8]

These books provide a general framework that expands and deepens the knowledge of the topic. A narrower timeframe was chosen to follow a relatively new topic and related efforts to provide the most up-to-date information and knowledge. Research in this area is prevalent, and discussions and new topics are continually opening up. Each author understands the concept of I4.0; otherwise, so many opinions agree and differ in many respects.

\section{Results}

The literature review in this article divided the results of the search into three primary groups. The first group of articles focuses only on business models, the second group of 
articles focuses on the role of business models in Industry 4.0, and the last group focuses on the use of the Canvas business model.

Table 2. Definitions of the results

\begin{tabular}{|l|l|}
\hline \multicolumn{1}{|c|}{ Author } & \multicolumn{1}{c|}{ Definition } \\
\hline Business models & $\begin{array}{l}\text { A business model reflects corporate activities that were realised } \\
\text { under the condition of a complex strategy. }\end{array}$ \\
\hline $\begin{array}{l}\text { Casadesus-Masanell, } \\
\text { Ricart, 2011 }\end{array}$ & $\begin{array}{l}\text { A business model expresses the logic that the facts and other data } \\
\text { support a value offer for the customer, and a possible structure of } \\
\text { revenues and costs for the firm delivering that value. }\end{array}$ \\
\hline Teece, 2010 & $\begin{array}{l}\text { It is created on the base of the interconnection of activities in the } \\
\text { company. These business activities must be multidisciplinary, } \\
\text { crossing boundaries of the company. }\end{array}$ \\
\hline Zott, Amit, 2010 & $\begin{array}{l}\text { They identify the factors that influence the new digitised business } \\
\text { models in Industry 4.0. } \\
\text { These factors are key performance indicators, individualisation, } \\
\text { efficiency and communication. }\end{array}$ \\
\hline Härting et al., 2019 & $\begin{array}{l}\text { They examine business models in Industry 4.0 and their } \\
\text { modifications and identified three super-patterns and ten sub- } \\
\text { patterns of I4.0 business models. }\end{array}$ \\
\hline Weking et al., 2019 & $\begin{array}{l}\text { The answer to previous results ranks among the widely used, } \\
\text { clear-cut and transparent business models. } \\
\text { The economic and social benefits of the business model. }\end{array}$ \\
\hline $\begin{array}{l}\text { Kühn et al., 2018; Urban } \\
\text { et al., 2018 }\end{array}$ & $\begin{array}{l}\text { The B.M. Canvas can help in use above all users who adopt profit } \\
\text { and purpose to support more sustainable value creation in itself. } \\
\text { Economic value orientation - "profit in the first place". }\end{array}$ \\
\hline $\begin{array}{l}\text { Osterwalder and Pigneur } \\
\text { 2010 }\end{array}$ &
\end{tabular}

Source: own work of authors

The research results present in the table above a high interest in the monitored topic. Based on a survey in the literature, a knowledge gap was found, which we would like to fill in the following research.

The primary idea is to be able to imagine the individual parts of the model as well as the model as a whole. This can be achieved by printing a large copy of the nine Canvas building blocks on a large paper or canvas (hence the name) and placing the copy on the wall so that more people can also look at the same model and think, discuss and imagine how to create the right business model. [27]

The Canvas business model includes in these definitions an architecture or business plan; content, structure and management of transactions; creating value through the use of business opportunities, economic value for customers: formulas, revenue and profit processes.

In this regard, we see a knowledge gap, and we want to use existing research at the level of understanding these areas. Subsequently, conduct research focused on the identification of key performance indicators in the Canvas business model in the Czech business environment for the manufacturing industry in the new era of 4.0.

\section{Discussion}

According to the literature used, the author summarises the fact that not only modern technology of today's age is undergoing dynamic development, but also organisations with 
their business models have to adapt to rapidly changing trends. The business model is a personal story that describes how a business works, what value it creates, whom it serves, and the way it generates profit. The main goal of each company should be to create a business model to ensure relatively sustainable or long-term growth and financial sustainability of the business.

\section{Conclusion}

This research will run until the end of February 2021. This literature review will be followed by the identification of key performance indicators according to their relevance and specification in the Canvas model used in manufacturing 4.0. The last step of the prepared research is the adjustment of this goal to the Czech business environment.

This research will make it easier for many companies to implement Industry 4.0 and can deepen their scientific knowledge in this area.

Assuming that the research and its goals are successfully met, it can be assumed that this system will be used by Czech entrepreneurs, to whom it can significantly help in their activities.

The author would like to thank the Internal Grant Agency of University No.: FP-J-20-6445 "Identification of key performance indicators in the Canvas business model in the Czech business environment for the manufacturing industry 4.0 " for providing financial support.

\section{References}

1. Weking, J., Stöcker, M., Kowalkiewicz, M., Böhm, M., Krcmar, H. (2019). Leveraging industry 4.0 - A business model pattern framework. International Journal of Production Economics, 225, 107588.

2. Siemens (2020). Industry 4.0. Retrieved from: https://www.siemens.cz/prumys140/.

3. Confederation of Industry of the Czech Republic (2019). Industry 4.0. Retrieved from : https://www.spcr.cz/prumysl-4-0.

4. Madsen, T., Servais, P. (1997). The internationalisation of born globals: An evolutionary process. International Business Review, 6(6), 561-583.

5. Zott, C., Amit, R., Massa, L. (2011). The business model: recent developments and future research. Journal of Management, 37(4), 1019-1042.

6. Daas, D., Hurkmans, T., Overbeek, S., Bouwman, H. (2012). Developing a decision support system for business model design. Electronic Markets, 23(3), 251-265.

7. Maurya, A. (2010). Why lean Canvas vs Business Model Canvas? Practice Trumps Theory. Retrieved from : http://practicetrumpstheory.com/2012/02/why-lean-canvas/

8. Osterwalder, A., Pigneur, Y., Clark, T. (2010). Business model generation: A handbook for visionaries, game changers, and challengers. Hoboken, NJ: John Wiley \& Sons.

9. Foss, N.J., Saebi, T. (2017). Fifteen years of research on business model innovation: how far have we come, and where should we go? Journal of Management, 43(1), 200227.

10. Amit, R., Zott, C. (2001). Value creation in e-business. Strategic Management Journal, 22(6-7), 493-520.

11. Casadesus-Masanell, R., Ricart, J. E. (2011). How to design a winning business model. Harvard Business Review, 89(1-2), 100-107. 
12. Franceschelli, M., V., Santoro, G., Candelo, E. (2018). Business model innovation for sustainability: a food start-up case study. British Food Journal, 120(10), 2483-2494.

13. Burmeister, CH., Lüttgens, D., Piller, F. T. (2016). Business model innovation for Industrie 4.0: why the "industrial internet" mandates a new perspective on innovation. Die Unternehmung, 70, 124-152

14. Teece, D. J. (2010). Business models, business strategy and innovation. Long Range Planning, 43(2/3), 172-194.

15. Bossidy, L., Charan, R., Burck, Ch. (2009). Execution: The discipline of getting things done. Crown Publishing Group.

16. Schmidt, R., Möhring, M., Härting, R. C., Reichstein, C., Neumaier, P., Jozinović, P. (2015). Industry 4.0 - Potentials for Creating Smart Products: Empirical Research results. International Conference on Business Information Systems (pp. 16-27), Cham: Springer.

17. Liao, Y., Deschamps, F., Loures, EDFR, Ramos, L.F.P. (2017). Past, present and future of Industry 4.0-a systematic literature review and research agenda proposal. International Journal of Producion Research, 55(12), 3609-3629.

18. Oesterreich, T.D., Teuteberg, F. (2016). Understanding the implications of digitisation and automation in the context of Industry 4.0: a triangulation approach and elements of a research agenda for the construction industry. Computers in Industry, 83, 121-139.

19. Babiceanu, R.F., Seker, R. (2016). Big Data and virtualisation for manufacturing cyberphysical systems: a survey of the current status and future outlook. Computers in Industry, 81, 128-137.

20. Müller, J.M., Buliga, O., Voigt, K.I. (2018). Fortune favors the prepared: how SMEs approach business model innovations in Industry 4.0. Technolological Forecasting and Social Change, 132, 2-17.

21. Rong, K., Hu, G., Lin, Y., Shi, Y., Guo, L. (2015). Understanding business ecosystem using a 6C framework in Internet-of-Things-based sectors. International Journal of Production Economics, 159 (SI), 41-55.

22. Brettel, M., Friederichsen, N., Keller, M., Rosengerg, M. (2014). How virtualisation, decentralisation and network building change the manufacturing landscape: an industry 4.0 perspective. International Journal of Information and Communication Engineering, $8(1), 37-44$.

23. de Man, J. C., Strandhagen, J. O. (2017). An Industry 4.0 research agenda for sustainable business models. Manufacturing System 4.0, 63, 721-726.

24. García-Muiña, FE., Medina-Salgado, MS., Ferrari, AM., Cucchi, M. (2020). Sustainability Transition in Industry 4.0 and Smart Manufacturing with the TripleLayered Business Model Canvas. Sustainability, 12(6), 2364.

25. Kühn, A., Joppen, R., Reinhart, F., Röltgen, D., von Enzberg, S., Dumitrescu, R. (2018). Analytics Canvas - A Framework for the design and specification of data analytics projects. In F. Laroche, A. Bernard (Eds.), 28th CIRP Design Conference (pp. 162-167). Amsterdam : Elsevier Science BV.

26. Domanižová, P., Milichovský, F., Kuba, K. (2019). Business models, strategy and innovation in the new world of digitization. Littera Scripta, 13(1), 17-31.

27. Daniel, E., Wilson, H., Myers, A. (2002). Adoption of e-commerce by SMEs in the UK. International Small Business Journal, 20(3), 253-270. 